\title{
MOTIVASI SISWA DALAM MEMANFAATKAN LAYANAN \\ BIMBINGAN DAN KONSELING
}

\section{Saidah Tunnor}

Universitas Achmad Yani Banjarmasin

\begin{abstract}
The purpose of the study is to obtain a description of what can motivate in utilizing guidance and counseling services in MAN 1 Banjarmasin. The data digging tool used is questionnaire and interview as a complement. Analysis of data in use is the formula percentage. From the results of data processing shows a small part $(36,886 \%)$ students who expressed always take advantage of guidance and counseling services on impulse ability, want to know, understand, apply in daily life and get parent support, education facilities, guidance from teacher BK (konselor), Support from friends, media counseling guidance services on the internet. A small portion (32.148\%) of students stated freqently. A small number (24.890\%) of students stated rarely. The smallest part $(6,074 \%)$ of students stated never. Finally based on the results of research can be concluded that a small part of the motivation of students in utilizing gudance and counseling services. Therefore it is necessary for the understanding and application of information about counseling guidance services in schools, so that between BP students and teachers or principals can work together well and responsibly.
\end{abstract}

Keywords: motivation, service, guidance and counseling 


\section{Pendahuluan}

Sekolah adalah salah satu bentuk lingkungan yang bertanggung jawab dalam memberikan asuhan terhadap proses perkembangan individu. Bimbingan dan konseling kepada individu akan memperoleh penyesuaian diri sesuai dengan tingkat perkembangannya.

Bimbingan merupakan bagian yang integral dari pendidikan, maka tujuannya diabdikan kepada tujuan pendidikan. Bimbingan membantu individu mengembangkan dirinya secara optimal, sehingga dapat menemukan dirinya dan dapat mengadakan pilihan keputusan dan penyesuaian diri secara efektif.

Semua Pendidikan diarahkan untuk mencapai tujuan nasional. Tujuan pendidikan nasional adalah :

Pendidikan nasional bertujuan untuk berkembangnya potensi peserta didik agar menjadi manusia yang beriman dan bertaqwa. kepada Tuhan Yang Maha Esa, berakhlaq mulia, sehat, berilmu, cakap, kreatif, mandiri, serta menjadi warga negara yang demokratis serta bertanggung jawab (UU 20, 2003).

Untuk mencapai tujuan pendidikan tersebut, bukanlah suatu hal yang mudah tetapi dengan memperhatikan kemungkinankemungkinan dan kenyataan tentang ada kesulitan yang dihadapi dalam rangka mengembangkan diri secara optimal, dengan memahami, mengarahkan, dan bertindak sesuai dengan tuntutan dan keadaan lingkungan sekolah, keluarga dan masyarakat.

\section{Pembahasan}

\section{A. Konsep Bimbingan dan Konseling}

Bimbingan dan konseling adalah pelayanan bantuan untuk peserta didik, baik secara perorangan maupun kelompok agar mandiri dan bisa berkembang secara optimal, dalam bimbingan pribadi, sosial, belajar maupun karier melalui berbagai jenis layanan dan kegiatan pendukung berdasarkan normanorma yang berlaku (SK Mendikbud No. 025/D/1995).

$$
\text { Dalam memanfaatkan }
$$

layanan bimbingan dan konseling siswa sangat dipengaruhi oleh adanya 
beberapa faktor, baik itu faktor dari dalam maupun dari luar. Seperti faktor lain siswa mempunyai keinginan mengembangkan dirinya, bakat dan minat, sehingga dapat memecahkan masalahnya sendiri secara bertanggung jawab. Faktor yang lain, seorang konselor mempunyai minat terhadap pekerjaan dengan orang lain dan harus mempunyai kemampuan, bertingkah laku sopan, ramah dan bijaksana.

Ada pula sebagian siswa yang tidak terlihat berminat untuk menyelesaikan masalahnya dengan cara memanfaatkan bimbingan konseling di sekolah. Di sisi lain program bimbingan konseling terutama layanan bimbingan pribadi tidak berfungsi sebagaimana mestinya.

Untuk menghindari adanya perbedaan persepsi pada judul penelitian, maka perlu kiranya dijelaskan beberapa istilah yang digunakan dalam penelitian ini, yaitu

1. Motivasi

Istilah motivasi (motivation) berasal dari bahasa
Latin, yakni movere yang berarti menggerakkan atau mendorong (to move). Sedangkan dalam kamus besar Bahasa Indonesia edisi ketiga (2001 : 756); motivasi merupakan dorongan yang timbul pada diri seseorang secara sadar atau spontan untuk melakukan suatu tindakan dengan tujuan tertentu.

Dalam Kamus Besar Bahasa Indonesia 1988 : 593 motivasi adalah 1) dorongan yang timbul pada diri seseorang sadar atau tidak sadar untuk melakukan suatu tindakan dengan tujuan tertentu; 2) usaha-usaha yang menyebabkan seseorang atau kelompok orang tertentu tergerak melakukan sesuatu karena ingin mencapai tujuan yang dikehendakmya atau mendapat keputusan dengan perbuatannya.

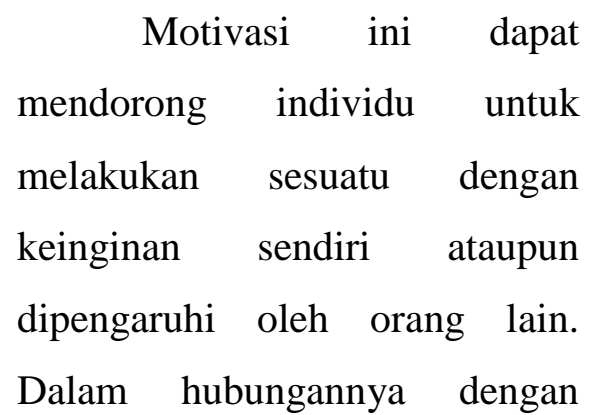


bimbingan dan konseling, motivasi merupakan dorongan dalam melakukan upaya memahami dan mengembangkan perilaku individu yang dilayani (klien). Konselor harus dapat memahami dan mengembangkan setiap motif dan motivasi yang melatarbelakangi perilaku individu yang dilayaninya (klien).

\section{Siswa}

Siswa adalah pelajar yang dapat dikatakan sebagai subyek dalam belajar di sekolah. Siswa yang ada di Madrasyah Aliyah Negeri 1 Banjarmasin dapat memanfaatkan layanan bimbingan dan konseling.

3. Manfaat

$$
\begin{aligned}
& \text { Manfaat artinya guna, } \\
& \text { faedah. Memanfaatkan } \\
& \text { merupakan suatu upaya dalam hal } \\
& \text { yang baik dengan memberikan } \\
& \text { berbagai macam jenis kegiatan } \\
& \text { yang dilakukan, sehingga bantuan } \\
& \text { tersebut dapat bermanfaat }
\end{aligned}
$$

4. Layanan

Layanan merupakan suatu bantuan yang memberikan cara dalam tujuan tertentu sesuai dengan apa yang akan disampaikan.

Layanan bimbingan konseling merupakan bentuk bantuan yang diberikan kepada individu oleh pihak sekolah dalam menyelenggarakan bimbingan dan konseling untuk mengatasi atau memecahkan masalah yang dihadapi oleh siswa.

\section{Bimbingan}

$$
\text { Bimbingan adalah }
$$

bantuan yang diberikan kepada individu (adalah hal ini peserta didik) sesuai dengan potensi kepada dimiliki mampu mengembangkan diri secara optimal dengan jalan memahami diri, memahami lingkungan hambatan guna menentukan rencana masa depan yang lebih baik.

6. Konseling

Konseling adalah suatu proses interaksi antara dua orang individu konselor dan klien, yang bersifat pribadi (profesional), 
diciptakan dan dibina sebagai suatu cara untuk memudahkan terjadinya perubahan-perubahan tingkah laku klien, sehingga memperoleh keputusan dalam memuaskan kebutuhannya.

\section{B. Metode Penelitian}

a. Alat Penggali Data

$$
\begin{aligned}
& \text { Alat atau teknik yang } \\
& \text { digunakan dalam kegiatan } \\
& \text { pengumpulan data pada suatu } \\
& \text { penelitian mempunyai kedudukan } \\
& \text { yang sangat menentukan. Dalam } \\
& \text { suatu penelitian, selain diperlukan } \\
& \text { tujuan yang jelas dan adanya data } \\
& \text { yang dapat dijadikan indikasi } \\
& \text { terhadap keadaan / sifat sesuatu } \\
& \text { yang diteliti juga dituntut } \\
& \text { penggunaan alat pengggali data } \\
& \text { yang sesuai atau relevan dengan } \\
& \text { jenis data yang akan } \\
& \text { dikumpulkan. }
\end{aligned}
$$

Untuk dapat menggali data yang diinginkan dalam penelitian maka digunakan alat untuk menggali data adalah sebagai berikut :

b. Angket
Angket merupakan alat penggali data utama dalam penelitian karena itu angket / daftar pertanyaan disusun sedemikian rupa sehingga benar-benar dapat menggali data secara lengkap dan cermat mengenai apa saja yang mempengaruhi motivasi siswa dalam memanfaatkan layanan bimbingan dan konseling di MAN 1 Banjarmasin.

c. Wawancara

Wawancara merupakan alat penggali data penunjang, hal ini untuk menjaring data dan informasi kepada siswa yang belum dapat dijaring melalui angket. Dilaksanakan terhadap sebagian siswa MAN 1 Banjarmasin untuk melengkapi pertanyaan yang belum tersedia pada angket.

b. Uji Coba Penggali Data

Angket yang diuji ini dianggap valid karena dalam pembuatan item-item masalahnya disesuaikan dengan masalah yang 
diteliti. Kemudian untuk menguji reliabilitas angket perlu diadakan uji coba (try out) terhadap 45 orang siswa MAN 1 Banjarmasin.

Tujuan dari uji coba ini antara lain untuk mengetahui tingkat kepercayaan angket dan juga untuk mengetahui apakah pertanyaan-pertanyaan pada angket terdapat penafsiran yang lain (salah) dari responden.

c. Analisis Validitas dan Reliabilitas Angket

Teknik yang digunakan dalam menganalisa uji coba angket untuk mengetahui validitas angket dilakukan dengan cara menganalisis skor angket masing-masing responden. Dengan menggunakan rumus product Moment dengan angka kasar, yaitu :

$r_{x y}=\frac{\sum \mathrm{xy}}{\sqrt{\left(\sum \mathrm{x}^{2}\right)\left(\sum \mathrm{y}^{2}\right)}}$

(Sutrisno Hadi, 1980 : 273)

Keterangan : $\mathrm{r}_{\mathrm{xy}}=$ Koefisien korelasi antara gejala $x$ dan gejala $y$

$\Sigma_{\mathrm{xy}}=$ Jumlah product dari $\mathrm{x}$ dan $\mathrm{y}$

$\mathrm{x}=$ Skor butir ganjil

$\mathrm{y}=$ Skor butir genap

\section{Pengolahan dan Analisa Data}

d. Pengumpulan Data

Setelah angket yang sudah dinyatakan valid dan reliabel maka disebarkan kepada siswa MAN 1 Banjarmasin sebagai subyek penelitian ini.

e. Pengolahan Data

Pengolahan data dalam penelitian ini melalui alat penggali data yang dikumpulkan melalui angket.

Angket yang telah dibagikan kepada seluruh siswa MAN 1 Banjarmasin. Pengolahan data penelitian ini adalah menggunakan rumus prosentase sebagai berikut :

$$
P=\frac{\mathrm{f}}{\mathrm{N}} \times 100 \%
$$

(Muhammad Ali, $1982: 184$ ) 
Keterangan :

$\mathrm{P}=$ Prosentase yang dicari

$\mathrm{f}=$ Frekuensi alternatif jawaban

yang dipilih siswa

$\mathrm{N}=$ Jumlah siswa yang diteliti

Selanjutnya data yang sudah diperoleh dan terkumpul melalui angket diolah dengan cara sebagai berikut :

a. Mendistribusikan terhadap alternatif jawaban pada setiap item dalam angket.

b. Mengalikan nilai jawaban yang menjawab alternatif jawaban tidak pernah kemudian dibagi dengan jumlah $\mathrm{N}$ (jumlah responden) dan selanjutnya dikali $100 \%$.

c. Mengalikan nilai jawaban yang menjawab alternatif jawaban jarang sekali dengan jumlah N (jumlah responden) dan selanjutnya dikali $100 \%$.

d. Mengalikan nilai jawaban yang menjawab alternatif jawaban sering dengan jumlah $\mathrm{N}$ (jumlah responden) dan selanjutnya dikali $100 \%$. e. Mengalikan nilai jawaban yang menjawab alternatif jawaban selalu dengan jumlah $\mathrm{N}$ (jumlah responden) dan selanjutnya dikali $100 \%$.

Dengan demikian akan diperoleh nilai rata-rata terhadap masingmasing alternatif jawaban dalam bentuk prosentase, maka dari hasil perhitungan prosentase tersebut kemudian di interpretasikan.

\section{Cara Penarikan Kesimpulan}

Setelah pengolahan data dan dianalisis, maka dapat ditarik kesimpulan sebagai berikut :

f. Apabila data menunjukkan $0 \%$ berarti tidak ada motivasi siswa dalam memanfaatkan layanan bimbingan dan konseling di MAN 1 Banjarmasin.

Apabila data menunjukkan 1$100 \%$ berarti ada motivasi siswa dalam memanfaatkan layanan bimbingan dan konseling di MAN 1 Banjarmasin.

\section{E. Hasil Penelitian}


Sebagian terkecil $(13,33 \%)$ siswa yang menjawab selalu mengungkapkan permasalahan yang dialami pada guru BP, dan yang lain cukup besar (46,67 \%) siswa yang menjawab sering mengungkapkan permasalahan yang dialami pada guru BP, kemudian sebagian kecil $(24,44$ $\%)$ siswa yang menjawab jarang sekali mengungkapkan permasalahan yang dialami pada guru BP, dan prosentase yang lain sebagian terkecil $(15,56 \%)$ siswa yang menjawab tidak pernah mengungkapkan permasalahan yang dialami pada guru BP. Dapat disimpulkan bahwa siswa sering mengungkapkan permasalahan yang dialami pada guru BP.

Sebagian kecil (37,78 \%) siswa yang menjawab selalu tertarik terhadap cara penyelesaian masalah yang dilakukan oleh guru BP, dan sebagian kecil juga (33,33 \%) siswa yang sering tertarik terhadap cara penyelesaian masalah yang dilakukan oleh guru BP, kemudian prosentase lain sebagian kecil $(24,44 \%)$ siswa yang menjawab jarang sekali tertarik terhadap cara penyelesaian masalah yang dilakukan oleh guru BP, dan yang lain sebagian terkecil $(4,44 \%)$ siswa yang menjawab tidak pernah tertarik terhadap cara penyelesaian masalah yang dilakukan oleh guru BP. Dapat disimpulkan bahwa siswa sebagian kecil selalu tertarik terhadap cara penyelesaian masalah yang dilakukan oleh guru BP.

$$
\text { Sebagian terkecil (20 \%) }
$$

siswa yang menjawab selalu merasa terpacu diri untuk belajar lebih optimal setelah melakukan konseling dari guru BP, dan prosentase yang lain cukup besar $(44,45 \%)$ siswa yang sering merasa terpacu diri untuk belajar lebih optimal setelah melakukan konseling dari guru BP, kemudian yang lain sebagian kecil $(24,44 \%)$ siswa yang menjawab jarang sekali merasa terpacu diri untuk belajar lebih optimal setelah melakukan konseling dari guru BP, dan yang lain sebagian terkecil $(11,11$ $\%)$ siswa yang menjawab tidak pernah merasa terpacu diri untuk belajar lebih optimal setelah melakukan konseling dari guru BP.

$\begin{array}{rll} & \text { Berdasarkan tabel di atas } \\ \text { dapat disimpulkan bahwa cukup }\end{array}$


besar siswa merasa terpacu diri untuk belajar lebih optimal setelah melakukan konseling dari guru BP.

Sebagian kecil (26,66 \%) siswa yang menjawab selalu dapat mengembangkan kemampuan yang dimiliki serta menyalurkan bakat dan minat di sekolah, dan prosentase yang lain cukup besar $(33,34 \%)$ siswa yang sering dapat mengembangkan kemampuan yang dimiliki serta menyalurkan bakat dan minat di sekolah, kemudian yang lain sebagian terkecil (20\%) siswa yang menjawab jarang sekali dapat mengembangkan kemampuan yang dimiliki serta menyalurkan bakat dan minat di sekolah, dan yang lain sebagian kecil (20\%) siswa yang menjawab tidak pernah dapat mengembangkan kemampuan yang dimiliki serta menyalurkan bakat dan minat di sekolah. Dapat disimpulkan bahwa cukup besar siswa dapat mengembangkan kemampuan yang dimiliki serta menyalurkan bakat dan minat di sekolah.

$$
\begin{gathered}
\text { Sebagian kecil }(33,33 \%) \\
\text { siswa yang menjawab selalu }
\end{gathered}
$$

mempunyai kepercayaan diri saat mengalami masalah pada situasi sekarang, dan yang lain sebagian terkecil $(15,56 \%)$ siswa yang sering mempunyai kepercayaan diri saat mengalami masalah pada situasi sekarang, kemudian prosentase yang lain cukup besar $(42,22 \%)$ siswa yang menjawab jarang sekali mempunyai kepercayaan diri saat mengalami masalah pada situasi sekarang, dan yang lain sebagian terkecil (20\%) siswa yang menjawab tidak pernah mempunyai kepercayaan diri saat mengalami masalah pada situasi sekarang.Dapat disimpulkan bahwa cukup besar siswa merasa mempunyai kepercayaan diri saat mengalami masalah pada situasi sekarang.

$$
\begin{aligned}
& \text { Sebagian kecil }(33,33 \%) \\
& \text { siswa yang menjawab selalu } \\
& \text { mempunyai kesadaran saat } \\
& \text { memutuskan solusi permasalahan } \\
& \text { yang diberikan oleh guru BP, dan } \\
& \text { prosentase yang lain cukup besar (40 } \\
& \%) \text { siswa yang sering mempunyai } \\
& \text { kesadaran saat memutuskan solusi }
\end{aligned}
$$


sebagian kecil $(26,67 \%)$ siswa yang menjawab jarang sekali mempunyai kesadaran saat memutuskan solusi permasalahan yang diberikan oleh guru BP, dan yang lain tidak ada (0 $\%)$ siswa yang menjawab tidak pernah mempunyai kesadaran saat memutuskan solusi permasalahan yang diberikan oleh guru BP. Dapat disimpulkan bahwa cukup besar siswa merasa mempunyai kesadaran saat memutuskan solusi permasalahan yang diberikan oleh guru BP.

Dapat ditafsirkan bahwa tidak ada (0 \%) siswa yang menjawab selalu merasa terbebani dengan tugas yang diberikan oleh guru-guru di sekolah, dan prosentase yang lain sebagian kecil $(26,67 \%)$ siswa yang sering merasa terbebani dengan tugas yang diberikan oleh guru-guru di sekolah, kemudian yang lain cukup besar $(46,66 \%)$ yang menjawab jarang sekali siswa merasa terbebani dengan tugas yang diberikan oleh guru-guru di sekolah, dan yang lain sebagian kecil $(26,67 \%)$ siswa yang menjawab tidak pernah merasa terbebani dengan tugas yang diberikan oleh guru-guru di sekolah.Dapat disimpulkan bahwa cukup besar siswa jarang sekali merasa terbebani dengan tugas yang diberikan oleh guru-guru di sekolah.

Sebagian besar $(62,22 \%)$ siswa yang menjawab selalu menyukai guru BP yang ramah, sopan dan bijaksana, dan prosentase yang lain sebagian terkecil (20\%) siswa yang sering menyukai guru BP yang ramah, sopan dan bijaksana, kemudian yang lain sebagian terkecil $(17,78 \%)$ yang menjawab jarang sekali siswa menyukai guru BP yang ramah, sopan dan bijaksana, dan yang lain tidak ada (0 \%) siswa yang menjawab tidak pernah menyukai guru BP yang ramah, sopan dan bijaksana. Dapat disimpulkan bahwa cukup besar siswa menyukai guru BP yang ramah, sopan dan bijaksana.

Cukup besar $(44,44 \%)$ siswa yang menjawab selalu merasa suatu kebutuhan untuk bersemangat dalam menyelesaikan masalah pribadi, dan prosentase yang lain sebagian kecil $(28,89 \%)$ siswa yang sering merasa suatu kebutuhan untuk bersemangat 
dalam menyelesaikan masalah pribadi, kemudian yang lain sebagian kecil (26,67 \%) yang menjawab jarang sekali siswa merasa suatu kebutuhan untuk bersemangat dalam menyelesaikan masalah pribadi, dan yang lain tidak ada (0 \%) siswa yang menjawab tidak pernah merasa suatu kebutuhan untuk bersemangat dalam menyelesaikan masalah pribadi. Dapat disimpulkan bahwa cukup besar siswa merasa suatu kebutuhan untuk bersemangat dalam menyelesaikan masalah pribadi.

Sebagian kecil (22,22 \%) siswa yang menjawab selalu memotivasi diri dalam kegiatan layanan yang diberikan guru BP di sekolah, dan prosentase yang lain cukup besar $(51,11 \%)$ siswa yang sering memotivasi diri dalam kegiatan layanan yang diberikan guru BP di sekolah, kemudian yang lain sebagian kecil (26,67 \%) yang menjawab jarang sekali siswa memotivasi diri dalam kegiatan layanan yang diberikan guru BP di sekolah, dan yang lain tidak ada (0\%) siswa yang menjawab tidak pernah, tidak memotivasi diri dalam kegiatan layanan yang diberikan guru BP di sekolah. Dapat disimpulkan bahwa cukup besar siswa memotivasi diri dalam kegiatan layanan yang diberikan guru BP di sekolah.

Cukup besar $(51,11 \%)$ siswa yang menjawab selalu merasa tertarik dengan media internet yang diperkenalkan guru bidang studi / guru BP di sekolah, dan prosentase yang lain sebagian terkecil (20\%) siswa yang sering merasa tertarik dengan media internet yang diperkenalkan guru bidang studi / guru BP di sekolah, kemudian yang lain sebagian kecil $(24,45 \%)$ yang menjawab jarang sekali siswa merasa tertarik dengan media internet yang diperkenalkan guru bidang studi / guru BP di sekolah, dan yang lain sebagian terkecil $(4,44 \%)$ siswa yang menjawab tidak pernah merasa tertarik dengan media internet yang diperkenalkan guru bidang studi / guru BP di sekolah.

\footnotetext{
Berdasarkan tabel di atas dapat disimpulkan bahwa cukup besar siswa merasa tertarik dengan media internet yang diperkenalkan
} 
guru bidang studi / guru BP di sekolah.

Cukup besar $(46,66 \%)$ siswa yang menjawab selalu mendapat informasi pemahaman masa pubertas dan remaja awal yang disampaikan guru BP, dan prosentase yang lain cukup besar $(44,44 \%)$ siswa yang sering mendapat informasi pemahaman masa pubertas dan remaja awal yang disampaikan guru $\mathrm{BP}$, kemudian yang lain sebagian terkecil $(8,90 \%)$ yang menjawab jarang sekali siswa mendapat informasi pemahaman masa pubertas dan remaja awal yang disampaikan guru BP, dan prosentase yang lain tidak ada (0\%) siswa yang menjawab tidak pernah mendapat informasi pemahaman masa pubertas dan remaja awal yang disampaikan guru BP. Dapat disimpulkan bahwa cukup besar siswa mendapat informasi pemahaman masa pubertas dan remaja awal yang disampaikan guru BP.

Sebagian kecil $(22,22 \%)$ siswa yang menjawab selalu merasa tertarik dengan materi layanan bimbingan konseling yang diberikan guru BP, dan prosentase yang lain sebagian kecil $(33,33 \%)$ siswa yang sering merasa tertarik dengan materi layanan bimbingan konseling yang diberikan guru BP, kemudian yang lain cukup besar $(44,45 \%)$ yang menjawab jarang sekali siswa merasa tertarik dengan materi layanan bimbingan konseling yang diberikan guru BP, dan prosentase yang lain tidak ada (0\%) siswa yang menjawab tidak pernah merasa tertarik dengan materi layanan bimbingan konseling yang diberikan guru BP.

Berdasarkan tabel di atas
dapat disimpulkan bahwa jarang
sekali siswa merasa tertarik dengan
materi layanan bimbingan konseling
yang diberikan guru BP.

Sebagian kecil (40 \%) siswa yang menjawab selalu mengetahui guru BP berpartisipasi dengan wali kelas / guru lain dalam melakukan bimbingan di sekolah, dan prosentase yang lain sebagian kecil $(35,56 \%)$ siswa yang sering mengetahui guru BP berpartisipasi dengan wali kelas / guru lain dalam melakukan 
bimbingan di sekolah, kemudian yang lain sebagian terkecil $(13,33 \%)$ yang menjawab jarang sekali siswa mengetahui guru BP berpartisipasi dengan wali kelas / guru lain dalam melakukan bimbingan di sekolah, dan prosentase yang lain sebagian terkecil $(11,11 \%)$ siswa yang menjawab tidak pernah mengetahui guru BP berpartisipasi dengan wali kelas / guru lain dalam melakukan bimbingan di sekolah.

Berdasarkan tabel di atas
dapat disimpulkan bahwa siswa
sebagian kecil mengetahui guru BP
berpartisipasi dengan wali kelas /
guru lain dalam melakukan
bimbingan di sekolah.
Interpretasi data :

$$
\begin{aligned}
& \text { Sebagian terbesar (86,67 \%) } \\
& \text { siswa yang menjawab selalu } \\
& \text { mengharapkan permasalahan yang } \\
& \text { dialami dapat diselesaikan dengan } \\
& \text { baik dan bertanggung jawab, dan } \\
& \text { prosentase yang lain sebagian terkecil } \\
& (13,33 \%) \text { siswa yang sering } \\
& \text { mengharapkan permasalahan yang } \\
& \text { dialami dapat diselesaikan dengan } \\
& \text { baik dan bertanggung jawab, }
\end{aligned}
$$

kemudian prosentase yang lain tidak ada (0 \%) yang menjawab jarang sekali siswa mengharapkan permasalahan yang dialami dapat diselesaikan dengan baik dan bertanggung jawab, dan prosentase yang lain tidak ada (0\%) siswa yang menjawab tidak pernah mengharapkan permasalahan yang dialami dapat diselesaikan dengan baik dan bertanggung jawab.

Berdasarkan tabel di atas
dapat disimpulkan bahwa siswa
sebagian terbesar selalu
mengharapkan permasalahan yang
dialami dapat diselesaikan dengan
baik dan bertanggung jawab.
Berdasarkan tabel di atas dapat disimpulkan bahwa siswa sebagian terbesar selalu mengharapkan permasalahan yang baik dan bertanggung jawab. 
TABEL 24

REKAPITULASI RATA-RATA

PROSENTASI TENTANG MOTIVASI

\begin{tabular}{|c|c|c|c|c|c|c|c|c|c|}
\hline \multirow{2}{*}{ No } & \multirow{2}{*}{ Indikator / Kegigan } & \multicolumn{2}{|r|}{ Selalin } & \multicolumn{2}{|c|}{ Sering } & \multicolumn{2}{|c|}{ Jarang Seali } & \multicolumn{2}{|c|}{ Tidak Permath } \\
\hline & & F & $\%$ & ? & $\%$ & F & $\%$ & $F$ & $\%$ \\
\hline 1. & Motivasi Intrinsik & & & & & & & & \\
\hline & Tabel 9 & 6 & 13,33 & 21 & 46,67 & 11 & 24,44 & 7 & 15,56 \\
\hline & Tabel 10 & 17 & 37,78 & 15 & 33,33 & 11 & 24,45 & 2 & 4,44 \\
\hline & Tabel 11 & 12 & 26,66 & 15 & 33,24 & 9 & 20 & 9 & 20 \\
\hline & Tabel 12 & 15 & 33,33 & 3 & 15,56 & 19 & 42,22 & 4 & 8,89 \\
\hline & Tabel 13 & 15 & 33,33 & 18 & 40 & 12 & 26,67 & . & . \\
\hline & Tabel 14 & 15 & 33,33 & 18 & 40 & 12 & 26,67 & . & . \\
\hline & Tabel 15 & $\cdot$ & . & 12 & 26,67 & 21 & 46,66 & 12 & 26,67 \\
\hline & Tabel 16 & 28 & 02,22 & 9 & 20 & 8 & 17,78 & . & . \\
\hline & Tabel 17 & 20 & 44,44 & 13 & 28,89 & 12 & 26,67 & . & . \\
\hline & Jimlah & & 284,42 & & 284,46 & & 255,56 & & 75,56 \\
\hline & Rata-rata & & 31,602 & & 31,606 & & 28,395 & & 8,395 \\
\hline 2. & Notirasi Ekstrinsik & & & & & & & & \\
\hline & Tabel 18 & 10 & 22,22 & 23 & 51,11 & 12 & 26,67 &. & . \\
\hline & Tabel 19 & 23 & 51,11 & 9 & 20 & 11 & 24,45 & 2 & 4,44 \\
\hline & Tabel 20 & 21 & 46,66 & 20 & 44,44 & 4 & 8,90 & $\cdot$ & - \\
\hline & Tabel 2! & 10 & 22,22 & 15 & 33,33 & 20 & 44,45 & . & . \\
\hline & Tabel 22 & 18 & 40 & 16 & 35,56 & 6 & 13,33 & 5 & 11,11 \\
\hline & Tabel 23 & 39 & 86,67 & 6 & 13,33 & $\cdot$ & . & . & . \\
\hline & Jumlah & & 268,88 & & 197,77 & & 117,8 & & 15,55 \\
\hline & Rata-rath & & 44,813 & & 32,961 & & 19,633 & & 2,591 \\
\hline & JumlahKerelunhas & & 553,3 & & 482,23 & & 373,36 & & $9,1,1$ \\
\hline & Rata-rata Keseluninhan & & 36,886 & & 32,148 & & 24,890 & & 6,074 \\
\hline
\end{tabular}

Berdasarkan hasil rekapitulasi rata-rata prosentasi tentang motivasi maka Dapat disimpulkan bahwa sebagian kecil $(36,886 \%)$ motivasi siswa dalam memanfaatkan layanan bimbingan dan konseling di MAN 1 Banjarmasin. Dari dalam diri siswa, meliputi dorongan kemampuan, ingin mengetahui, memahami, menerapkan dalam kehidupan sehari-hari. Dari luar diri siswa meliputi: mendapat dukungan orang tua, sarana pendidikan, bimbingan dari guru BK (konselor), dukungan dari temanteman, media layanan bimbingan konseling di internet.

\section{Simpulan}

Berdasarkan hasil dan pengolahan data tentang motivasi siswa dalam memanfaatkan layanan bimbingan dan konseling di MAN 1 Banjarmasin, maka dapat disimpulkan yaitu :

1. Motivasi siswa memanfaatkan layanan bimbingan dan konseling di MAN 1 Banjarmasin sebagian kecil.

a. Motivasi Intrinsik

$$
\begin{aligned}
& \text { Sebagian kecil } \\
& (31,602 \%) \quad \text { siswa yang } \\
& \text { menyatakan selalu } \\
& \text { memanfaatkan layanan } \\
& \text { bimbingan dan konseling } \\
& \text { karena dorongan kemampuan, }
\end{aligned}
$$


sehari-hari. Di samping itu juga sebagian kecil $(31,606 \%)$ siswa yang menyatakan sering memanfaatkan layanan bimbingan dan konseling karena dorongan kemampuan, ingin mengetahui, memahami, menerapkan dalam kehidupan sehari-hari. Yang lain juga sebagian keeil $(28,395 \%)$ siswa yang menyatakan jarang sekali memanfaatkan layanan bimbingan dan konseling karena dorongan kemampuan, ingin mengetahui, memahami, menerapkan dalam kehidupan sehari-hari. Sebagian terkecil $(8,395 \%) \quad$ siswa yang menyatakan tidak pernah memanfaatkan layanan bimbingan dan konseling karena dorongan kemampuan, ingin mengetahui, memahami, menerapkan dalam kehidupan sehari-hari.

b. Motivasi Ekstrinsik

Cukup besar $(44,813 \%)$ siswa yang menyatakan selalu mendapat dukungan orang tua, sarana pendidikan, bimbingan dari guru BK (konselor), dukungan dari teman-teman, media layanan bimbingan konseling di Internet. Sebagian kecil $(32,961 \%)$ siswa yang menyatakan sering mendapat dukungan orang tua, sarana pendidikan, bimbingan dari guru BK (konselor), dukungan dari teman-teman, media layanan bimbingan konseling di Internet. Sebagian terkecil $(19,633 \%) \quad$ siswa yang menyatakan jarang sekali mendapat dukungan orang tua, sarana pendidikan, bimbingan dari guru BK (konselor), dukungan dari teman-teman, media layanan bimbingan konseling di Internet.

Sebagian terkecil $(2,591 \%) \quad$ siswa yang menyatakan tidak pernah mendapat dukungan orang tua, sarana pendidikan, bimbingan dari guru BK (konselor), dukungan dari teman-teman, media layanan bimbingan konseling di Internet. 
2. Motivasi Intrinsik dan Ekstrinsik

Sebagian kecil $(36,886 \%)$ siswa yang menyatakan selalu memanfaatkan layanan bimbingan dan konseling karena dorongan kemampuan, ingin mengetahui, memahami, menerapkan dalam kehidupan sehari-hari serta mendapat dukungan orang tua, sarana pendidikan, bimbingan dari guru BK (konselor), dukungan dari temanteman, media layanan bimbingan konseling di Internet. Sebagian kecil $(32,148 \%)$ siswa yang menyatakan sering. Sebagian kecil $(24,890 \%)$ siswa yang menyatakan jarang sekali. Sebagian terkecil $(6,074 \%)$ siswa yang menyatakan tidak pernah.

Berdasarkan kesimpulan di atas, peneliti mengajukan saran sebagai berikut:

1. Siswa hendaknya mengungkapkan permasalahan yang dialami sehingga dapat memudahkan solusi permasalahan yang akan dipecahkan secara bertanggung jawab.
2. Kepala sekolah diharapkan dapat memberikan arahan / mengorganisir para guru ataupun guru BK dalam pelaksanaan program bimbingan dan konseling di sekolah.

3. Wali kelas hendaknya saling bekerja sama dengan guru BK untuk mengatasi masalah yang dialami siswa.

4. Untuk guru BP hendaknya lebih memahami siswa dan mengetahui kemampuan bakat dan minat yang dimiliki sesuai dengan tingkat perkembangan fisik dan psikisnya, sehingga dalam menyampaikan layanan bimbingan konseling dapat terlaksana dengan baik.

5. Kepada peneliti yang akan datang agar dapat melanjutkan penelitian yang serupa di tempat atau sekolah lain.

\section{Daftar Pustaka}

Abu Ahmadi, 1991. Bimbingan dan Konseling di Sekolah. PT. Rineka Cipta : Jakarta.

Abdurrahmat Fathoni, 2006. Metodologi Penelitian dan Teknik Penyusunan Skripsi. PT. Rineka Cipta : Jakarta. 
Martin Handoko, 1992. Motivasi Daya Penggerak Tingkah Laku. Kanisius : Yogyakarta.

Djumhur, 1975. Bimbingan dan Penyuluhan di Sekolah (Guidance \& Counseling). CV. Ilmu : Bandung.

Mukhiar, 2007. Diktat Layanan Konseling Diperluas. UVAYA : Banjarmasin.

Sumadi Suryabrata, 1983. Metodologi Penelitian. PT. Raja Grafindo Persada : Jakarta.Ubaedy, 2008. Motivasi Untuk Hidup Yang Lebih Baik. Bee Media Indonesia : Jakarta. 